\title{
INTERNATIONAL EVIDENCE ON VACCINES AND THE MORTALITY TO INFECTIONS RATIO IN THE PRE-OMICRON ERA
}

\author{
Joshua Aizenman \\ Alex Cukierman \\ Yothin Jinjarak \\ Weining Xin \\ Working Paper 29498 \\ http://www.nber.org/papers/w29498
NATIONAL BUREAU OF ECONOMIC RESEARCH 1050 Massachusetts Avenue
Cambridge, MA 02138

November 2021, Revised January 2023

We would like to thank two anonymous referees and the editor for useful suggestions. Joshua Aizenman is grateful for the support provided by the Dockson Chair in Economics and International Relations, USC. The views expressed herein are those of the authors and do not necessarily reflect the views of the National Bureau of Economic Research, the Asian Development Bank, and the International Monetary Fund.

NBER working papers are circulated for discussion and comment purposes. They have not been peer-reviewed or been subject to the review by the NBER Board of Directors that accompanies official NBER publications.

(C) 2021 by Joshua Aizenman, Alex Cukierman, Yothin Jinjarak, and Weining Xin. All rights reserved. Short sections of text, not to exceed two paragraphs, may be quoted without explicit permission provided that full credit, including $\left({ }^{\circ}\right.$ notice, is given to the source. 
International Evidence on Vaccines and the Mortality to Infections Ratio in the Pre-Omicron

Era

Joshua Aizenman, Alex Cukierman, Yothin Jinjarak, and Weining Xin

NBER Working Paper No. 29498

November 2021, Revised January 2023

JEL No. F42,F44,I18

\section{ABSTRACT}

Prior to the appearance of the Omicron variant, observations on countries like the UK that have accumulated a large fraction of inoculated individuals suggest that, although initially, vaccines have little effect on new infections, they strongly reduce the share of mortality out of a given pool of infections. This paper examines the extent to which this phenomenon is more general by testing the hypothesis that the ratio of lagged mortality to current infections is decreasing in the total number of vaccines per one hundred individuals in the pre-Omicron period, in a pooled time-series, cross-section sample with weekly observations for up to 208 countries. The main finding is that vaccines moderate the share of mortality from a given pool of lagged infections at sufficiently high levels of vaccination rates, which is essentially a favorable shift in the tradeoff between life preservation and economic performance. The practical lesson is that, in the presence of a sufficiently high share of inoculated individuals, governments can shade down containment measures, even as infections are still rampant, without significant adverse effects on mortality.

Joshua Aizenman

Economics and SIR

University of Southern California

University Park

Los Angeles, CA 90089-0043

and NBER

aizenman@usc.edu

Alex Cukierman

Tel-Aviv University

School of Economics

Tel-Aviv 69978

ISRAEL

alexcuk@tauex.tau.ac.il
Yothin Jinjarak

ERCD

Asian Development Bank

Mandaluyong City 1550

Metro Manila, Philippines

yothin.jinjarak@vuw.ac.nz

Weining Xin

International Monetary Fund

700 19th St NW

Washington, DC 20431

WXin@imf.org 


\section{Introduction}

Since its outbreak in early 2020 the Covid19 pandemic confronted governments all over the world with a painful tradeoff between containment of its adverse consequences for public health and economic activity. Prior to the appearance of vaccines in early 2021 the main instrument available to policymakers for choosing a point along this tradeoff included various containment measures designed to reduce contagion by limiting individual and business contacts. Along this tradeoff more stringent measures would reduce contagion at the cost of reduced economic activity.

The capacity of medical systems to handle large quantities of Covid19 casualties and serious illness is limited. Two crucial indicators of the ability of the medical system to confront the pandemic from both a practical and social point of view are mortality and serious illness. A third, less stringent, indicator, is the number of infected individuals. An important reason for watching this variable is the fact that a certain fraction of infected individuals induces, with a lag, mortality and serious illness. A fourth variable is the stock of recovered patients that may eventually contribute to herd immunity. However, it may add some pressure on the medical system in the medium to long term due to the 'long Covid.'

Reduction in the adverse consequences of the pandemic due to the gradual administration of vaccines to the population opened the door for experimentation with milder containment measures. This improved the tradeoff and opened the door for more efficient outcomes on both the pandemic and the economy. A natural presumption is that, other things the same, countries with larger fractions of inoculated population should benefit more from this process. Moreover, due to lags in the beneficial effects of vaccines, countries with relatively low shares of vaccinated population may not benefit at all. On the other hand, countries with relatively high shares may be able to reduce or even eliminate stringent containment measures with relatively little risk of renewed infections and Covid19 mortality. Obviously, such considerations figure prominently in the strategies followed by policymakers.

The main objective of this paper is to test the hypothesis that, once the total level of vaccinations has reached a sufficiently high level, the incidence of mortality out of a given pool of infected individuals goes down. This hypothesis was initially motivated by the experience of Great Britain prior to the appearance of the Omicron variant in November 2021. After peaking 
during winter 20/21 both new cases and new deaths shrank dramatically leveling at very low levels around April 21. Since this happened at relatively low levels of

Figure 1: Total vaccinations, mortality, and new cases in Great Britain

New weekly deaths and total vaccinations per 100 individuals lagged by two weeks

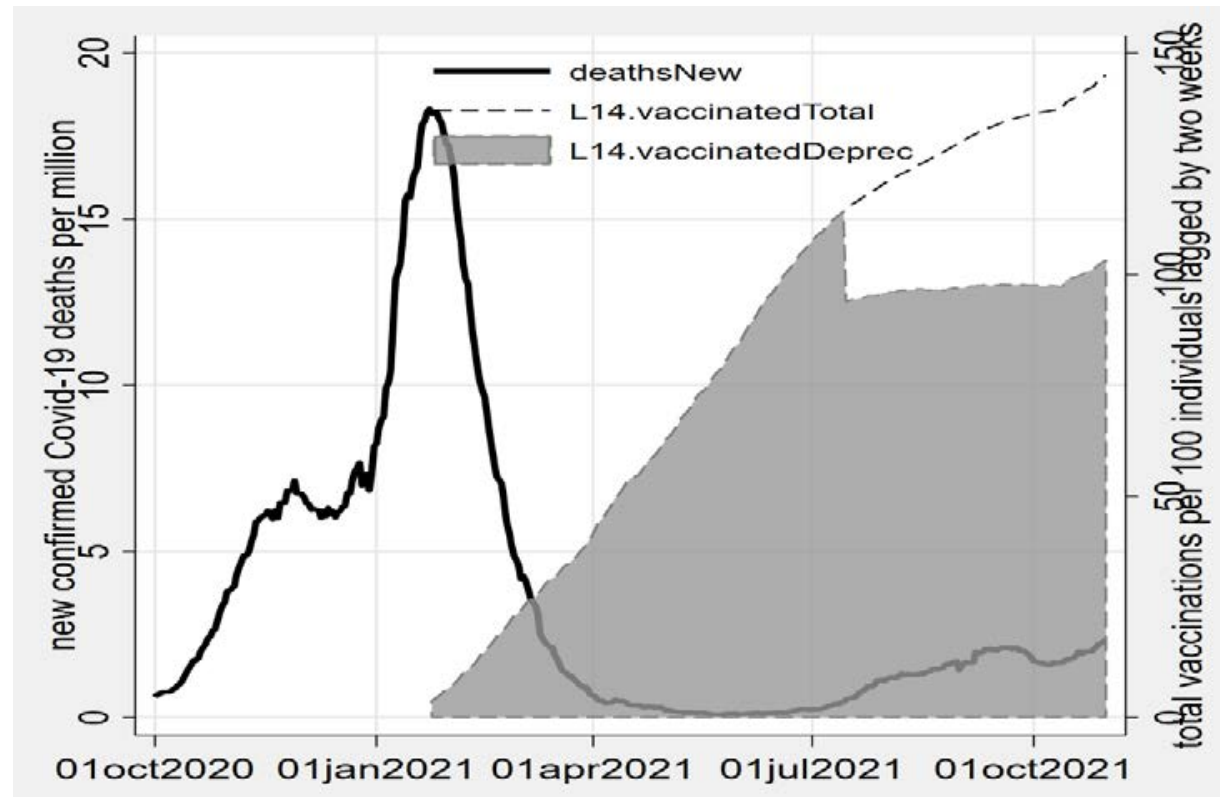

New weekly infection and total vaccinations per 100 individuals lagged by two weeks

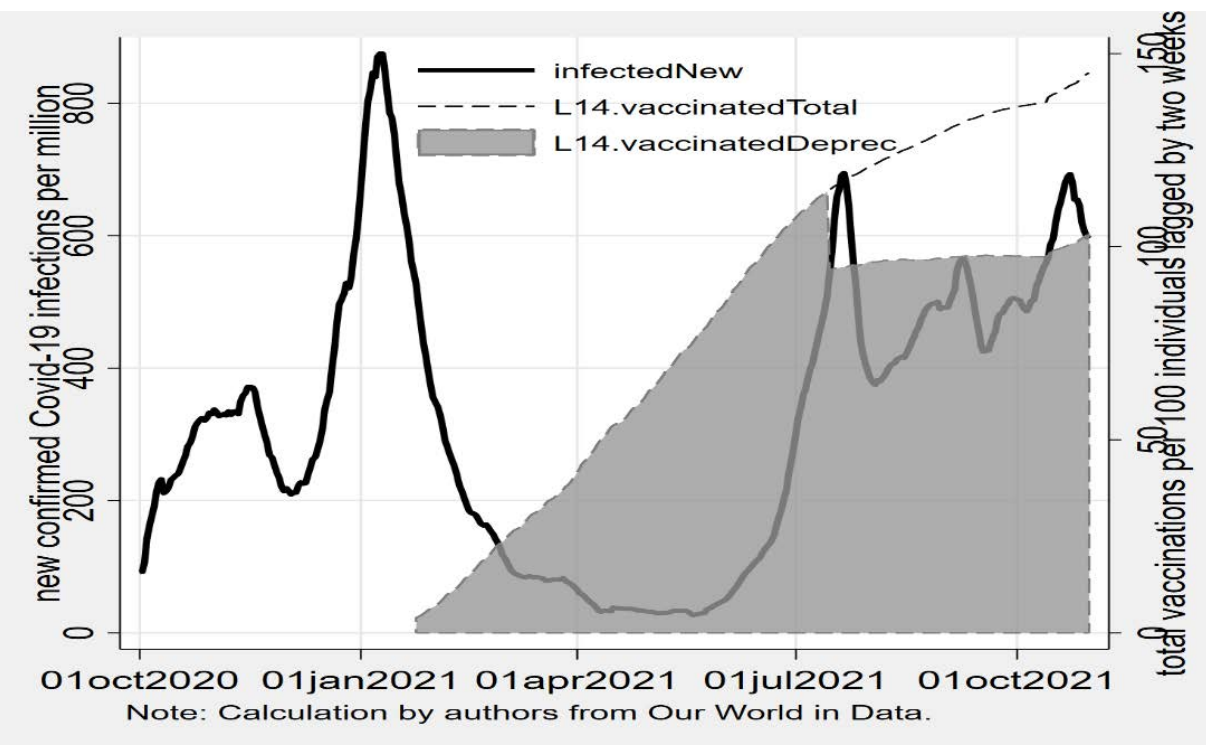

cumulative vaccinations this descent from the peak was probably due mainly to reasons other than vaccines (Figure 1). ${ }^{2}$ Encouraged by those developments prime minister Johnson gradually

${ }^{2}$ The figures show both total cumulated vaccines (outer envelope of the union of the two shaded areas) as well as total cumulated vaccines after correction for vaccine depreciation (outer envelope of the dark shaded area). The 
eased containment measures and finally abolished them completely on July 1, 2021. Following those policy changes new cases rebounded but, contrary to the winter 20/21-episode, new deaths remained relatively dormant. A main difference between the two cases is that during February 2021 the vaccination process was just starting whereas on July 1, 2021, cumulative vaccinations were above 110 vaccines per 100 individuals.

The British experience suggests that, although the impact of sufficiently high level of cumulated vaccines on new cases is relatively muted its moderating effect on new deaths is substantial leading to the hypothesis that the ratio between new deaths and new cases lagged is negatively related to the cumulative level of vaccines. ${ }^{3}$ A main objective of this paper is to test whether this hypothesis applies more generally when a large number of countries with different characteristics is considered. Limited sensitivity analysis to account for waning of vaccines and changing intensities of variants of concern (VOC) is conducted. ${ }^{4}$ The limitations are dictated by data availability.

To our knowledge this hypothesis has not been tested previously. The closest paper to ours is Karabulut et. al. (2021). They investigate the impact of democracy on Covid19 outcomes. One of their main findings is that the mortality/infections ratio in a cross section of countries is negatively related to the level of democracy. Our focus is on the impact of vaccines on this ratio, and we use a combined time series cross-sectional data.

paper proceeds by first discussing and presenting results prior to this correction and then replicates those results with the correction.

${ }^{3}$ A similar, although less dramatic, phenomenon has been observed in Israel. Medical research suggests that there is a lag of about two to three weeks between new cases and their impact on new deaths.

${ }^{4}$ We follow a classification proposed by the WHO according to which variants of concern include the following variants: Alpha, Beta, Gamma, Delta and Omicron. 


\section{Empirical design and results for the mortality to infection ratio}

Our sample consists of weekly observations on a bunch of variables described later starting at various dates during the first quarter of 2020 and ending on October $312021 .{ }^{5}$ The sample is cut on this date in order to isolate the impact of vaccines on the mortality/infection ratio from the decrease in this ratio due to the emergence of the less lethal Omicron variant. ${ }^{6}$ Much of the data is drawn from the site of "Our World in Data". ${ }^{7}$ A detailed description of the data and its sources appears in the data appendix. The basic estimated regression is

$M L I_{i t}=\beta_{0}+\beta_{1} M L I_{i, t-1}+\beta_{2} V_{i, t-2}+\beta_{3} S_{i, t-1}+\beta_{4} R_{i, t}+\beta_{5} Y_{i}+\beta_{6} O L D_{i}+\varepsilon_{i, t}$

, where $M L I_{i t}$ is the ratio between new deaths in week $t$ and a two-week lag on bi-weekly new infections in country $i$. The indices $i$ and $t$ represent respectively the country and week. $V$ is the cumulated number of vaccines per 100 individuals, $S$ is a measure of stringency of containment measures imposed by government, $R$ is a cumulated measure of recovered individuals per million, calculated as the difference between cumulative cases and deaths, $Y$ is income per capita in 2019 and $O L D$ is the fraction of individuals above 65 in $2019 .{ }^{8}$ The variable $R$ is introduced to capture a potentially growing herd immunity effect that might appear after a sufficient fraction of the population recovers from corona infections. The lagged dependent variable accounts for serial correlation in $M L I$.

The $M L I$ measure is akin to the case fatality rate $(C F R)$, which is the ratio between confirmed deaths and confirmed cases. Other two common measures are Infection Fatality Rate (IFR), which is the ratio of the number of deaths caused by a given disease and the number of

\footnotetext{
${ }^{5}$ The sample includes up to 208 countries and territories. The cross-country variation in starting dates is due to data limitations.

${ }^{6}$ Accumulating recent medical evidence suggests that the mortality/infection ratio of Omicron is lower than that of its predecessors such as the delta variant.

${ }^{7}$ Available at the GitHub repository: https://github.com/owid/covid-19-data/tree/master/public/data.

${ }^{8}$ Prior to the appearance of vaccines, the main instrument used by government to moderate the pandemic was the imposition of various restrictions on mobility and mandatory face masks. Hale et. al. (2020) provide a quantitative index for the stringency of those containment measures. Balazs et. al. (2020) investigate the impact of such measures on the reproduction rate of the virus and the economy. Using daily panel data in a cross section of countries along with Hale et. al. (op. cit.) stringency index, Deb et. al. (2020) and Jinjarak et. al. (2020) estimate the impact of level of stringency on the development of the pandemic. Hubert finds that, during the early stages of the pandemic restrictions on air travel were particularly effective in containing the spread of the virus.
} 
people that contract the disease. Focacci et al. (2022) assess the efficiency of CFR, IFR, and crude Mortality in informing policymaker and the public about the consequences of the virus. They highlight the advantage of CFR in capturing the pandemic's gravity, which is the purpose of our $M L I$ measure.

Estimation is carried out by least squares, with standard errors clustered by country and region. It is applied to the entire sample, as well as to three bins of observations grouped according to cumulated vaccination rates: Low $(V<40)$, medium $(40<V<80)$, High $(V>80)$. Table 1 presents three linear regression models; one for the full sample, the second for the high vaccination bin, and the third for the low vaccinations bin. The last column presents a logarithmic version for the entire sample. The logarithmic version is included in the spirit of robustness in order to examine the extent to which the main result is sensitive to the functional form chosen. Except for the low vaccination bin regression vaccines have a negative and significant impact on the mortality to infections ratio. In the medium bin vaccines have no significant impact on the mortality/infection ratio (regression not shown). Sensitivity analysis consisting of dropping some of the insignificant regressors in Table 1 reveals that, for high levels of vaccination, the impact of vaccines is always significantly negative but is not uniformly significant for lower levels of vaccinations (regressions not shown).

This supports the view that most of the moderating impact of vaccines on $M L I_{i t}$ materializes at sufficiently high levels of total vaccination rates. Although occasionally negative the stringency variable and the fraction of recovered individuals are insignificant in all regressions. The second result is consistent with the view that herd immunity has not been achieved at both the world and the high and low bins vaccines levels. The impact of income per capita is invariably negative and significant while that of the lagged dependent is invariably positive and significant. 
Table 1: Impact of vaccines on the mortality to infections ratio

\begin{tabular}{|c|c|c|c|c|}
\hline \multirow[t]{2}{*}{\begin{tabular}{|l} 
Regressor \\
\end{tabular}} & \multicolumn{3}{|c|}{$\begin{array}{l}\text { Linear Regressions, Dependent variable: } \\
M L I_{i t}\end{array}$} & \multirow{2}{*}{$\begin{array}{l}\text { Logarithmic } \\
\text { Regression, Dependent } \\
\text { variable: } \log \left(M L I_{i t}\right) \\
\text { Full Sample }\end{array}$} \\
\hline & Full Sample & $\begin{array}{l}\text { High } \\
\underline{\text { Vaccinations }}\end{array}$ & $\begin{array}{l}\underline{\text { Low }} \\
\underline{\text { Vaccinations }}\end{array}$ & \\
\hline$M L I_{i, t-1}$ & $\begin{array}{l}0.71 * * * \\
(0.09)\end{array}$ & $\begin{array}{l}0.38 * * \\
(0.09)\end{array}$ & $\begin{array}{l}0.81^{* * *} \\
(0.05)\end{array}$ & $\begin{array}{l}0.86^{* * *} \\
(0.02)\end{array}$ \\
\hline$V_{i, t-2}$ & $\begin{array}{l}-0.02 * \\
(0.01)\end{array}$ & $\begin{array}{l}-0.03^{*} \\
0.01)\end{array}$ & $\begin{array}{l}-0.09 \\
(0.04)\end{array}$ & $\begin{array}{l}-0.02^{*} \\
(0.01)\end{array}$ \\
\hline$S_{i, t-1}$ & $\begin{array}{l}-0.02 \\
(0.02)\end{array}$ & $\begin{array}{l}0.00 \\
(0.05)\end{array}$ & $\begin{array}{l}-0.04 \\
(0.02)\end{array}$ & $\begin{array}{l}0.02 \\
(0.03)\end{array}$ \\
\hline$R_{i, t}$ & $\begin{array}{l}-0.06 \\
(0.08)\end{array}$ & $\begin{array}{l}0.03 \\
(0.07)\end{array}$ & $\begin{array}{l}-0.00 \\
(0.09)\end{array}$ & $\begin{array}{l}0.01 \\
(0.02)\end{array}$ \\
\hline$Y_{i}$ & $\begin{array}{l}-0.07^{*} \\
(0.02)\end{array}$ & $\begin{array}{l}-0.10^{* * *} \\
(0.01)\end{array}$ & $\begin{array}{l}-0.06^{*} \\
(0.02)\end{array}$ & $\begin{array}{l}-0.06^{*} \\
(0.02)\end{array}$ \\
\hline$O L D_{i}$ & $\begin{array}{l}0.01 \\
(0.04)\end{array}$ & $\begin{array}{l}-0.04 \\
(0.04)\end{array}$ & $\begin{array}{l}-0.04 \\
(0.04)\end{array}$ & $\begin{array}{l}0.02 \\
(0.01)\end{array}$ \\
\hline Intercept & $\begin{array}{l}8.35^{* *} \\
(1.47)\end{array}$ & $\begin{array}{l}11.95^{* *} \\
(2.04)\end{array}$ & $\begin{array}{l}8.75^{*} \\
(2.88)\end{array}$ & $\begin{array}{l}0.39 * * \\
(0.07)\end{array}$ \\
\hline F-stats. & 597.5 & 65.1 & 326.9 & 2210.2 \\
\hline $\begin{array}{l}\text { Adj. R- } \\
\text { squared }\end{array}$ & 0.51 & 0.22 & 0.56 & 0.81 \\
\hline $\begin{array}{l}\text { Number of } \\
\text { observations }\end{array}$ & 3478 & 1334 & 1558 & 3069 \\
\hline
\end{tabular}

Standard errors in parenthesis under the coefficients. $* \mathrm{P}<0.05$, ${ }^{* *} \mathrm{P}<0.01,{ }^{* * *} \mathrm{P}<0.001$

$M L I_{i t}$ is the ratio between new deaths in week $t$ and a two-week lag on bi-weekly new infections in country $i$. The indices $i$ and $t$ represent respectively the country and week. $V$ is the cumulated number of vaccines per 100 individuals, $S$ is a measure of stringency of containment measures imposed by government, $R$ is a cumulated measure of recovered individuals per million, calculated as the difference between cumulative cases and deaths, $Y$ is income per capita in 2019 and $O L D$ is the fraction of individuals above 65 in 2019. Further details and sources appear in the appendix. 


\section{Impact of vaccines on new infections}

This section examines whether vaccines also have a moderating effect on new infections. This is done by replacing $M L I_{i t}$ and $M L I_{i, t-1}$ in equation (1) by new infections in country i at time $\mathrm{t}\left(I_{i t}\right)$ and new infections lagged $\left(I_{i, t-1}\right)$,

$\Delta I_{i t}=\beta_{0}+\beta_{1} \Delta I_{i, t-1}+\beta_{2} V_{i, t-2}+\beta_{3} S_{i, t-1}+\beta_{4} R_{i, t}+\beta_{5} Y_{i}+\beta_{6} O L D_{i}+\varepsilon_{i, t}$

Estimation of linear regressions for dependent variable $I_{i t}$ rather than for its first difference for the full sample as well as for high and low vaccination bins reveals that $I_{i t}$ is close to being nonstationary (regressions not shown). To address this problem the dependent variable in equation (2) is specified as $\Delta I_{i t}$ rather than $I_{i t}$. Table 2 shows regression results for the full sample and for the high and low vaccination bins for this version. The main finding is that in all cases the impact of vaccines on new infections is insignificant. This is also the case for logarithmic versions of the full sample as well as for all the regressions in which the dependent variable is the level of infections. 
Table 2: Impact of vaccines on new infections

\begin{tabular}{|c|c|c|c|}
\hline \multirow[t]{2}{*}{ Regressor } & \multicolumn{3}{|c|}{ Linear Regressions, Dependent variable: $\Delta I_{i t}$} \\
\hline & Full Sample & $\begin{array}{l}\underline{\text { High }} \\
\underline{\text { Vaccinations }}\end{array}$ & $\begin{array}{l}\underline{\underline{\text { Low }}} \\
\underline{\text { Vaccinations }}\end{array}$ \\
\hline$\Delta I_{i, t-1}$ & $\begin{array}{l}0.33^{*} \\
(0.12)\end{array}$ & $\begin{array}{l}0.17 \\
(0.18)\end{array}$ & $\begin{array}{l}0.49 * * * \\
(0.03)\end{array}$ \\
\hline$V_{i, t-2}$ & \begin{tabular}{|l|}
0.04 \\
$(0.05)$
\end{tabular} & $\begin{array}{l}-0.05 \\
(0.03)\end{array}$ & $\begin{array}{l}-0.01 \\
(0.17)\end{array}$ \\
\hline$S_{i, t-1}$ & $\begin{array}{l}-0.27 \\
(0.12)\end{array}$ & $\begin{array}{l}-0.51^{*} \\
(0.15)\end{array}$ & $\begin{array}{l}-0.11 \\
(0.10)\end{array}$ \\
\hline$R_{i, t}$ & $\begin{array}{l}-1.08^{* *} \\
(0.26)\end{array}$ & $\begin{array}{l}-1.00 \\
(0.82)\end{array}$ & $\begin{array}{l}-1.09 \\
(0.77)\end{array}$ \\
\hline $\mathrm{Y}_{\mathrm{i}}$ & $\begin{array}{l}-0.05 \\
(0.07)\end{array}$ & $\begin{array}{l}0.05 \\
(0.09)\end{array}$ & $\begin{array}{l}-0.05 \\
(0.06)\end{array}$ \\
\hline$O L D_{i}$ & $\begin{array}{l}0.37 \\
(0.18)\end{array}$ & $\begin{array}{l}1.21^{*} \\
(0.36)\end{array}$ & $\begin{array}{l}0.14 \\
(0.30)\end{array}$ \\
\hline Intercept & $\begin{array}{l}16.87 \\
(6.56)\end{array}$ & $\begin{array}{l}25.43^{*} \\
(6.50)\end{array}$ & $\begin{array}{l}9.69 \\
(6.29)\end{array}$ \\
\hline F-stats & 77.7 & 13.8 & 90.7 \\
\hline $\begin{array}{l}\text { Adj. R- } \\
\text { squared }\end{array}$ & 0.12 & 0.05 & 0.26 \\
\hline $\begin{array}{l}\text { Number of } \\
\text { observations }\end{array}$ & 3482 & 1338 & 1558 \\
\hline
\end{tabular}

Standard errors in parenthesis under the coefficients. ${ }^{*} \mathrm{P}<0.05, * * \mathrm{P}<0.01,{ }^{*} * * \mathrm{P}<0.001$

$M L I_{i t}$ is the ratio between new deaths in week $t$ and a two-week lag on bi-weekly new infections in country $i$. The indices $i$ and $t$ represent respectively the country and week. $V$ is the cumulated number of vaccines per 100 individuals, $S$ is a measure of stringency of containment measures imposed by government, $R$ is a cumulated measure of recovered individuals per million, calculated as the difference between cumulative cases and deaths, $Y$ is income per capita in 2019 and $O L D$ is the fraction of individuals above 65 in 2019. Further details and sources appear in the appendix. 


\section{A detailed look at the data by finer bins}

Table 3 shows the number of weekly observations used in in the regressions of Table 1a of the following section. For robustness purposes all observations with cumulative vaccines below 80 is decomposed into 3 bins producing altogether the following four bins: [0, 40), [40, 60), [60, 80), $[80,$.$) . The last row of the table shows that over fifty percent of the sample observations are located in the$ lower bin, 24 percent in the upper bin and the around ten percent in the two intermediate bins.

Summary statistics by bins for all the sample variables appear in the first section of the Appendix.

Table 3: Number of weekly observations by vaccination thresholds (per hundred) and countries

\begin{tabular}{|c|c|c|c|c|}
\hline Country & $\begin{array}{r}\text { Threshold: } \\
{[0,40)}\end{array}$ & $\begin{array}{r}\text { Threshold: } \\
{[40,60)}\end{array}$ & $\begin{array}{r}\text { Threshold: } \\
{[60,80)} \\
\end{array}$ & $\begin{array}{r}\text { Threshold: } \\
{[80, .)}\end{array}$ \\
\hline Afghanistan & 4 & 0 & 0 & 0 \\
\hline Albania & 19 & 7 & 5 & 0 \\
\hline Andorra & 10 & 3 & 2 & 3 \\
\hline Angola & 12 & 0 & 0 & 0 \\
\hline Antigua and Barbuda & 2 & 1 & 4 & 2 \\
\hline Argentina & 24 & 4 & 4 & 11 \\
\hline Armenia & 2 & 0 & 0 & 0 \\
\hline Australia & 22 & 4 & 2 & 8 \\
\hline Austria & 19 & 4 & 3 & 18 \\
\hline Azerbaijan & 14 & 6 & 4 & 5 \\
\hline Bahamas & 1 & 0 & 0 & 0 \\
\hline Bahrain & 5 & 3 & 2 & 27 \\
\hline Bangladesh & 29 & 0 & 0 & 0 \\
\hline Barbados & 11 & 8 & 9 & 6 \\
\hline Belarus & 1 & 0 & 0 & 0 \\
\hline Belgium & 19 & 4 & 2 & 19 \\
\hline Belize & 7 & 4 & 3 & 1 \\
\hline Benin & 3 & 0 & 0 & 0 \\
\hline Bhutan & 1 & 1 & 8 & 5 \\
\hline Bolivia & 25 & 10 & 1 & 0 \\
\hline Bosnia and Herzegovina & 1 & 0 & 0 & 0 \\
\hline Botswana & 15 & 0 & 0 & 0 \\
\hline Brazil & 22 & 5 & 4 & 10 \\
\hline Brunei & 15 & 1 & 1 & 3 \\
\hline Bulgaria & 39 & 1 & 0 & 0 \\
\hline Burkina Faso & 6 & 0 & 0 & 0 \\
\hline
\end{tabular}




\begin{tabular}{|c|c|c|c|c|}
\hline Cambodia & 19 & 3 & 3 & 12 \\
\hline Cameroon & 16 & 0 & 0 & 0 \\
\hline Canada & 21 & 3 & 3 & 19 \\
\hline Cape Verde & 8 & 0 & 0 & 0 \\
\hline Central African Republic & 4 & 0 & 0 & 0 \\
\hline Chad & 4 & 0 & 0 & $\underline{0}$ \\
\hline Chile & 11 & 3 & 4 & 25 \\
\hline China & 10 & 2 & 2 & 18 \\
\hline Colombia & 18 & 5 & 5 & 4 \\
\hline Comoros & 4 & 0 & 0 & 0 \\
\hline Congo & 1 & 0 & 0 & 0 \\
\hline Costa Rica & 19 & 4 & 4 & 7 \\
\hline Cote d'Ivoire & 30 & 0 & 0 & 0 \\
\hline Croatia & 14 & 4 & 9 & 9 \\
\hline Cuba & 3 & 2 & 4 & 12 \\
\hline Cyprus & 1 & 3 & 1 & 12 \\
\hline Czech Republic & 20 & 4 & 3 & 17 \\
\hline $\begin{array}{l}\text { Democratic Republic of } \\
\text { Congo }\end{array}$ & 10 & 0 & 0 & 0 \\
\hline Denmark & 21 & 3 & 3 & 18 \\
\hline Djibouti & 1 & 0 & 0 & 0 \\
\hline Dominica & 4 & 3 & 0 & 0 \\
\hline Dominican Republic & 9 & 2 & 4 & 15 \\
\hline Ecuador & 25 & 1 & 3 & 10 \\
\hline Egypt & 7 & 0 & 0 & 0 \\
\hline El Salvador & 9 & 2 & 3 & 10 \\
\hline Equatorial Guinea & 8 & 0 & 0 & 0 \\
\hline Estonia & 19 & 5 & 5 & 15 \\
\hline Eswatini & 5 & 0 & 0 & 0 \\
\hline Ethiopia & 24 & 0 & 0 & 0 \\
\hline Fiji & 1 & 0 & 2 & 4 \\
\hline France & 20 & 3 & 4 & 17 \\
\hline Gabon & 7 & 0 & 0 & 0 \\
\hline Gambia & 2 & 0 & 0 & 0 \\
\hline Georgia & 19 & 4 & 0 & 0 \\
\hline Germany & 19 & 3 & 3 & 19 \\
\hline Ghana & 10 & 0 & 0 & 0 \\
\hline Greece & 20 & 3 & 4 & 17 \\
\hline Grenada & 4 & 0 & 0 & 0 \\
\hline Guatemala & 28 & 4 & 0 & 0 \\
\hline Guinea & 18 & 0 & 0 & 0 \\
\hline Guinea-Bissau & 5 & 0 & 0 & 0 \\
\hline Guyana & 3 & 6 & 3 & 0 \\
\hline
\end{tabular}




\begin{tabular}{|c|c|c|c|c|}
\hline Haiti & 6 & 0 & 0 & 0 \\
\hline Honduras & 4 & 2 & 0 & 0 \\
\hline Hong Kong & 17 & 4 & 3 & 12 \\
\hline Hungary & 12 & 3 & 3 & 3 \\
\hline Iceland & 12 & 0 & 1 & 0 \\
\hline India & 30 & 5 & 5 & 0 \\
\hline Indonesia & 30 & 5 & 2 & 0 \\
\hline Iran & 13 & 3 & 0 & 2 \\
\hline Iraq & 8 & 0 & 0 & 0 \\
\hline Ireland & 19 & 4 & 3 & 18 \\
\hline Israel & 5 & 2 & 3 & 35 \\
\hline Italy & 19 & 3 & 4 & 18 \\
\hline Jamaica & 4 & 0 & 0 & 0 \\
\hline Japan & 18 & 3 & 2 & 13 \\
\hline Jordan & 8 & 7 & 5 & 0 \\
\hline Kazakhstan & 12 & 5 & 9 & 0 \\
\hline Kenya & 21 & 0 & 0 & 0 \\
\hline Kiribati & 1 & 1 & 0 & 0 \\
\hline Kuwait & 5 & 0 & 0 & 0 \\
\hline Kyrgyzstan & 14 & 0 & 0 & 0 \\
\hline Laos & 10 & 2 & 0 & 0 \\
\hline Latvia & 24 & 5 & 9 & 8 \\
\hline Lebanon & 24 & 10 & 0 & 0 \\
\hline Lesotho & 3 & 0 & 0 & 0 \\
\hline Liberia & 4 & 0 & 0 & 0 \\
\hline Libya & 2 & 0 & 0 & 0 \\
\hline Liechtenstein & 19 & 2 & 3 & 17 \\
\hline Lithuania & 19 & 4 & 4 & 17 \\
\hline Luxembourg & 19 & 3 & 3 & 18 \\
\hline Madagascar & 6 & 0 & 0 & 0 \\
\hline Malawi & 23 & 0 & 0 & 0 \\
\hline Malaysia & 20 & 2 & 2 & 11 \\
\hline Maldives & 5 & 5 & 3 & 24 \\
\hline Mali & 10 & 0 & 0 & 0 \\
\hline Malta & 11 & 4 & 2 & 23 \\
\hline Mauritania & 11 & 0 & 0 & 0 \\
\hline Mauritius & 3 & 0 & 1 & 3 \\
\hline Mexico & 27 & 4 & 7 & 4 \\
\hline Moldova & 17 & 3 & 0 & 0 \\
\hline Mongolia & 4 & 1 & 3 & 18 \\
\hline Montenegro & 13 & 11 & 9 & 0 \\
\hline Morocco & 17 & 8 & 3 & 2 \\
\hline
\end{tabular}




\begin{tabular}{|c|c|c|c|c|}
\hline Mozambique & 6 & 0 & 0 & 0 \\
\hline Myanmar & 1 & 0 & 0 & 0 \\
\hline Namibia & 14 & 0 & 0 & 0 \\
\hline Nepal & 16 & 5 & 0 & 0 \\
\hline New Zealand & 25 & 3 & 2 & 7 \\
\hline Nicaragua & 1 & 0 & 0 & 0 \\
\hline Niger & 4 & 0 & 0 & 0 \\
\hline Nigeria & 13 & 0 & 0 & 0 \\
\hline North Macedonia & 10 & 4 & 2 & 0 \\
\hline Norway & 21 & 4 & 3 & 17 \\
\hline Oman & 17 & 1 & 2 & 4 \\
\hline Pakistan & 9 & 0 & 0 & 0 \\
\hline Panama & 5 & 0 & 0 & 0 \\
\hline Papua New Guinea & 4 & 0 & 0 & 0 \\
\hline Paraguay & 24 & 4 & 0 & 0 \\
\hline Peru & 24 & 5 & 4 & 4 \\
\hline Philippines & 21 & 4 & 0 & 0 \\
\hline Poland & 17 & 4 & 5 & 11 \\
\hline Qatar & 3 & 3 & 3 & 19 \\
\hline Romania & 22 & 21 & 1 & 0 \\
\hline Russia & 19 & 7 & 4 & 0 \\
\hline Rwanda & 6 & 0 & 0 & 0 \\
\hline Saint Kitts and Nevis & 1 & 0 & 1 & 5 \\
\hline Saint Lucia & 7 & 2 & 0 & 0 \\
\hline $\begin{array}{l}\text { Saint Vincent and the } \\
\text { Grenadines }\end{array}$ & 8 & 0 & 0 & 0 \\
\hline Samoa & 1 & 4 & 0 & 2 \\
\hline Sao Tome and Principe & 12 & 0 & 0 & 0 \\
\hline Saudi Arabia & 16 & 6 & 3 & 12 \\
\hline Senegal & 20 & 0 & 0 & 0 \\
\hline Serbia & 6 & 3 & 4 & 5 \\
\hline Seychelles & 3 & 1 & 2 & 7 \\
\hline Sierra Leone & 5 & 0 & 0 & 0 \\
\hline Singapore & 16 & 4 & 3 & 20 \\
\hline Slovenia & 20 & 4 & 7 & 13 \\
\hline Solomon Islands & 5 & 0 & 0 & 0 \\
\hline South Africa & 26 & 0 & 0 & 0 \\
\hline South Korea & 19 & 5 & 2 & 9 \\
\hline South Sudan & 12 & 0 & 0 & 0 \\
\hline Spain & 18 & 4 & 3 & 16 \\
\hline Sri Lanka & 21 & 2 & 1 & 10 \\
\hline Sudan & 5 & 0 & 0 & 0 \\
\hline Suriname & 12 & 7 & 5 & 0 \\
\hline
\end{tabular}




\begin{tabular}{|c|c|c|c|c|}
\hline Switzerland & 21 & 3 & 3 & 18 \\
\hline Syria & 6 & 0 & 0 & 0 \\
\hline Tajikistan & 4 & 1 & 0 & 0 \\
\hline Tanzania & 1 & 0 & 0 & 0 \\
\hline Thailand & 22 & 3 & 1 & 3 \\
\hline Timor & 3 & 1 & 0 & 0 \\
\hline Togo & 2 & 0 & 0 & 0 \\
\hline Tonga & 1 & 2 & 2 & 0 \\
\hline Trinidad and Tobago & 16 & 4 & 8 & 0 \\
\hline Tunisia & 22 & 4 & 5 & 0 \\
\hline Turkey & 21 & 3 & 4 & 13 \\
\hline Uganda & 15 & 0 & 0 & 0 \\
\hline Ukraine & 34 & 1 & 0 & 0 \\
\hline United Arab Emirates & 4 & 3 & 4 & 28 \\
\hline United Kingdom & 10 & 4 & 4 & 24 \\
\hline United States & 14 & 3 & 3 & 26 \\
\hline Uruguay & 7 & 3 & 3 & 22 \\
\hline Uzbekistan & 4 & 3 & 1 & 0 \\
\hline Vanuatu & 3 & 0 & 0 & 0 \\
\hline Venezuela & 4 & 1 & 0 & 0 \\
\hline Vietnam & 25 & 3 & 2 & 0 \\
\hline Yemen & 3 & 0 & 0 & 0 \\
\hline Zambia & 14 & 0 & 0 & 0 \\
\hline Zimbabwe & 32 & 0 & 0 & 0 \\
\hline $\begin{array}{l}\text { Total weekly observations } \\
\text { (percent of observations in } \\
\text { bin }\end{array}$ & $\begin{array}{r}2181 \\
(57)\end{array}$ & $\begin{array}{r}398 \\
(11)\end{array}$ & $\begin{array}{r}312 \\
(8) \\
\end{array}$ & $\begin{array}{r}919 \\
(24) \\
\end{array}$ \\
\hline
\end{tabular}

\section{Robustness experiments}

\section{5a. Experimentation with different bins}

To assess the sensitivity of the results to the choice of bins Table 1a replicates Table 1with a finer division into bins for vaccination levels below 80. Except for the lowest $[0,40)$ bin there is no significant impact of vaccinations on the mortality/infection ratio. ${ }^{9}$ By contrast this impact in the upper [80,.) bin is significant at the 0.01 level confirming Table's 1 result that the negative impact of vaccines on the mortality/infection originates mainly from levels above the 80 threshold.

${ }^{9}$ The mildly negative impact of vaccines on the CFR may be due to the fact that the proportion of old individuals in the lowest bin is lower than that in all the other bins as can be seen for this variable in the summary statistics table. 


\section{Table 1a: Impact of vaccines on the mortality to infections ratio - different bins}

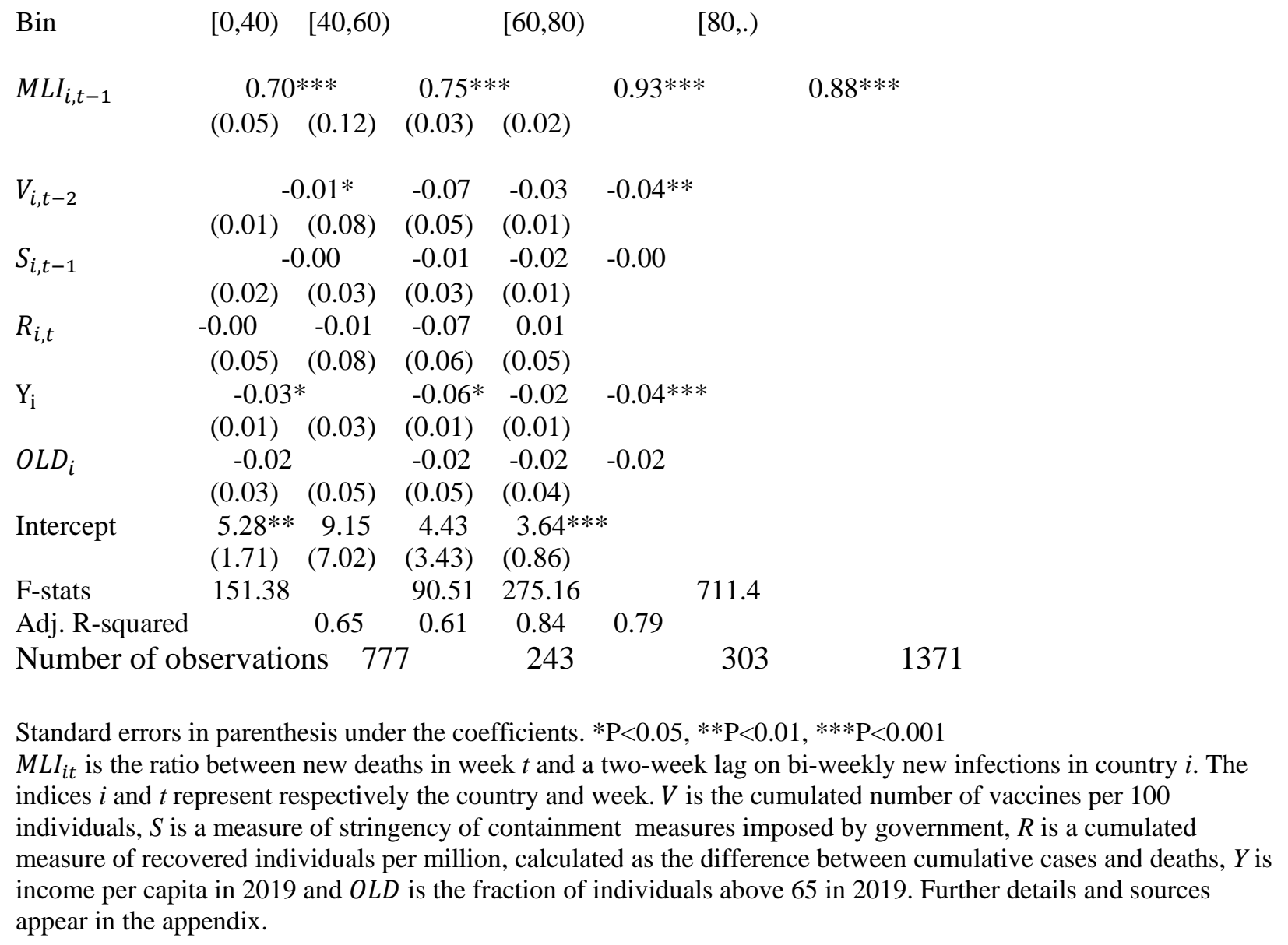

\section{5b. Accounting for waning in the effectiveness of vaccines on the mortality/infection ratio}

Medical tests have shown that the effectiveness of vaccines diminishes gradually as the time elapsed since inoculation increase. Although existing data on the rate of depreciation by type of vaccine does not make it possible to account for different rates of depreciation it is possible to obtain a ballpark rate of depreciation by using information on the rate of depreciation of Pfizer's vaccine. Medical sources report that after 5 months the effectiveness of Pfizer's vaccine goes down from $90 \%$ to $30 \%$. This implies that, on average, over half of this period (two and a half months or 11 weeks) the effectiveness of a given stock of vaccines is lower by half of the difference between $90 \%$ and $30 \%$ normalized by $90 \%$. More precisely $V_{t}^{a d}=V_{t}-\frac{0.3}{0.9} V_{t-11}$ where $V_{t}^{a d}$ is the cumulated number of vaccines per 100 individuals adjusted for depreciation. Since during the first 
six months of 2021 cumulated vaccines were relatively low this correction is applied only from July 1, 2021. The upper contour of the dark shaded area in the two panel of Figure 1 shows the value of $V_{t}^{a d}$ for the UK.

Table $1 \mathrm{a}$ in the appendix replicates table 1 with $V_{t}$ replaced by $V_{t}^{a d}$. Results are similar to those of Table 1 and even a bit stronger as the impact of $V_{t}^{a d}$ on the mortality/infection ratio is negative and significant in all four regressions.

\section{5c. Accounting for waning in the effectiveness of vaccines on infections}

Table 2a in the appendix replicates table 2 with $V_{t}$ replaced by $V_{t}^{a d}$. Except for the low vaccination bin all the regressions in the table show that the impact of vaccines on infections is insignificant. Along with table 1a of the appendix this implies that the main result of the paper is robust with respect to the vaccine depreciation adjustment - in the pre-Omicron period depreciation adjusted vaccines reduce the mortality/infection ratio.

\section{5d. Accounting for interactions between dominant variants and vaccines ${ }^{10}$}

The effectiveness of vaccines varies across different variants. Unfortunately, as of yet, no comprehensive data by countries and time periods is available. But the Institute of Social and Preventive Medicine at the University of Bern and the SIB Swiss Institute of Bioinformatics have been collecting reported sequences of actual genetic composition of the virus reported by various institutions within each country. Data points represent how many sequences came from each country within each two weeks' period and are meant to be proxies for the proportion of each variant in each country during the period. The quality of those proxies varies directly with the number of sequences reported. ${ }^{11}$

\footnotetext{
${ }^{10}$ We gratefully acknowledge all data contributors, i.e., the Authors and their Originating laboratories responsible for obtaining the specimens, and their Submitting laboratories for generating the genetic sequence and metadata and sharing via the GISAID Initiative, on which this subsection of the research is based. See also Elbe et.al. (2017). Emma Hodcroft graciously helped us with the interpretation of the sequencing data.

${ }^{11}$ For countries with significant sequencing such as the US and Western European countries, that are turning in thousands of sequences every 2 weeks, it is very likely that the sequence counts provide a pretty good approximation of the variants circulating in the country. However, if a country is only turning in a few sequences every few weeks, these may not be representative of the country.
} 
To detect differences in the effectiveness of vaccines we focus on dominant variants in a country within each two weeks' period. A dominant variant is defined as a variant with the highest proportion of sequence counts in a given country within a given two weeks' period. Figure 2 illustrates the distribution of variants over time for the UK. The figure shows that between January 11, 2021, and May 17, 2021 the dominant variant in the UK was Alpha, from May 17, 2021 till December 13, 2021 it was Delta and thereafter Omicron became the dominant variant. ${ }^{12}$ Over the entire sample of countries there are five dominant variants: Alpha, Beta, Gamma, Delta and Other variants.

To detect possible differences in the effectiveness of vaccines in the face of different dominant variants we reproduce modified versions of tables 1 and 2 with interaction terms between depreciated cumulative vaccines and each variant controlling for Stringency, share of Recovered individuals, GDP per capita and share of Old population (above age 65). This is implemented by defining a dummy variable that is equal to 1 for the prevailing dominant variant and 0 otherwise. Tables $1 \mathrm{~b}$ and $2 \mathrm{~b}$ in the appendix show respectively the impacts of those variables on the mortality/infection ratio and on new infections.

The broad message of Table $1 \mathrm{~b}$ is that the impact of vaccines on the mortality/infection ratio differs across dominant variants. In the presence of a sufficiently high level of cumulated vaccinations the impact is significantly negative when Delta and Alpha are the dominant variants but is insignificant when either Beta or Other Variants dominate. The mildly significantly positive impact in the presence of a dominant Gamma variant is the only outcome at variance with our main result. There are no significant impacts at low cumulated levels of vaccinations. The broad message of Table $2 \mathrm{~b}$ is that vaccines also have some negative impact on new infections. For observations with high levels of cumulated vaccinations this is the case for the Beta. Gamma and Delta variants.

\footnotetext{
${ }^{12}$ Since we focus on the pre-Omicron period this last period is not included in our sample.
} 
Figure 2: Proportions of variants in the UK between July 2020 and January 2022

\section{齿 United Kingdom}

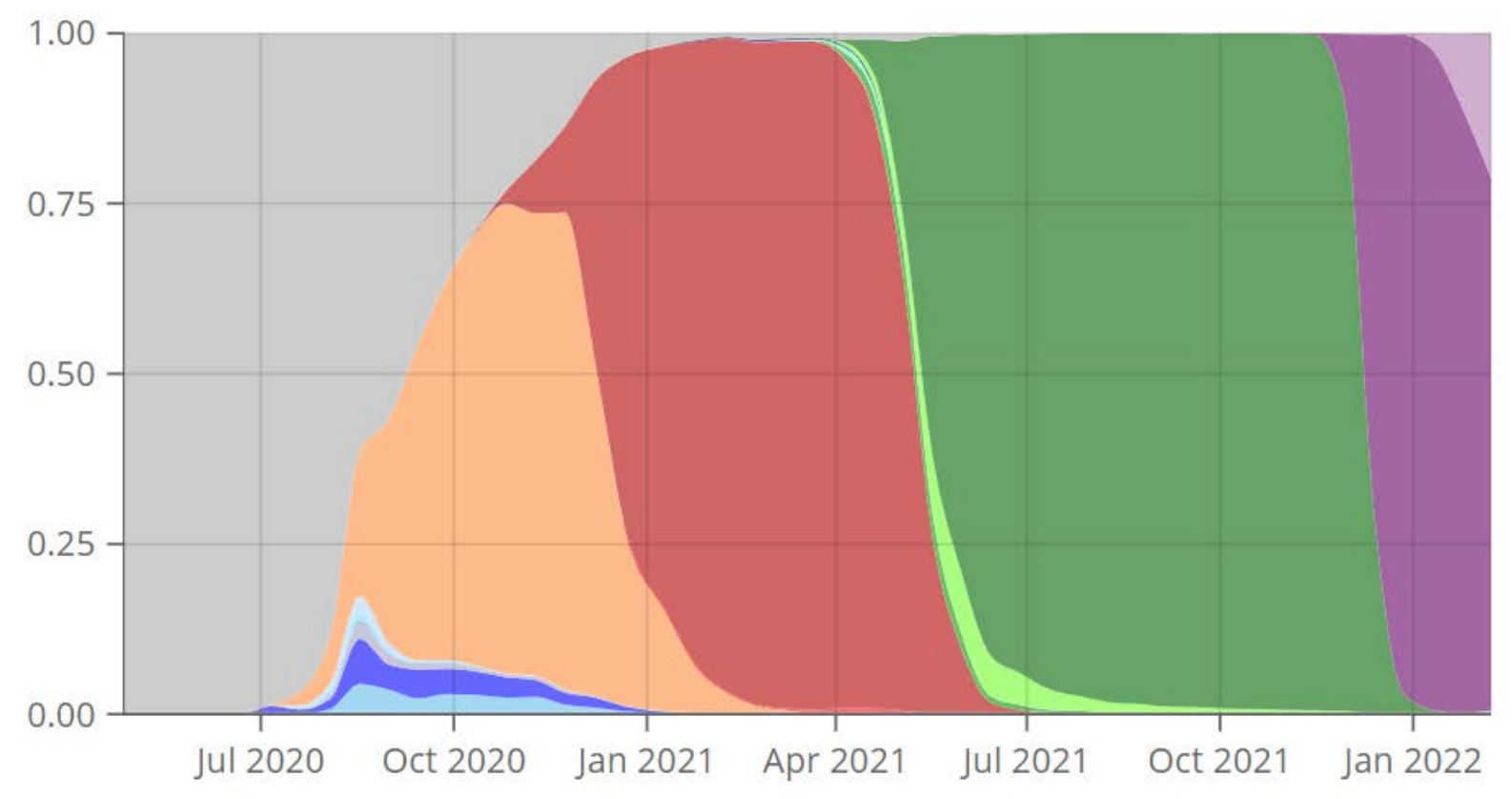

Color legend: Light Orange - EU1; Brown - Alpha; Green - Delta; Violet - Omicron

Source: https://covariants.org/per-country

\section{Concluding remarks}

The main conclusion from the statistical analysis of the paper is that vaccines, moderate the share of mortality from a given pool of lagged infections at sufficiently high levels of total vaccinations rates. But it does not support the view that vaccines also moderate infections to the same extent. ${ }^{13}$ Cognizance of this regularity by policymakers that are concerned with both mortality prevention and economic performance cannot be overemphasized. Avoiding lockouts and other stringent confinement measures stimulates the economy at the cost of an increase in the pool of infected individuals. But given that, in the presence of vaccines, this increase is associated with lower mortality, governments can provide better performance on both mortality

\footnotetext{
${ }^{13}$ Robustness experiments accounting for depreciation in the effectiveness of vaccines and differences in dominant variants across countries and time periods introduce nuances into this result but are still broadly consistent with it.
} 
avoidance and economic performance. This is essentially a favorable shift in the tradeoff between life preservation and economic performance. ${ }^{14}$

As far as we know this was a relatively novel regularity in the pre-Omicron period and was therefore unlikely to be fully appreciated by many governments at the time. In particular, the UK government lifted most of its Covid19 restrictions on July 19, 2021, even as infection cases were climbing vigorously. Whether this action was based on solid medical knowledge about the impact of vaccines on the mortality/infection ratio or on a response to public corona fatigue is an open question. Be that as it may figure 1 clearly indicates that the lifting of restrictions resulted in a substantially higher increase in new infections than in new mortality.

A similar, although less extreme, route was followed in Israel. The Green Pass and Purple Badge systems, which had set guidelines for who can enter public venues and how those venues can operate, expired starting June 1, meaning that Israelis no longer required proof of vaccination or recovery to enter various venues, and capacity limits at stores, restaurants and other sites were lifted. Although it reinstated some temporary minor restrictions in the face of rising infections in August 2021 the general policy of the Bennett government was to accelerate the vaccination process including booster shots to the entire population rather than re-tighten restrictions. ${ }^{15}$ Between July and mid-September infections shot up from less than 1000 per day to over 10000 . During part of this period daily mortality was initially zero, subsequently increasing to a modest peak in mid-September before receding to around 7 daily deaths at the end of October. The decrease in new infections since the mid-September peak is probably due to a vigorous booster campaign that raised total vaccinations to 180 per hundred individuals. This countered the decrease in the effectiveness of original vaccinations many of which became older than 5 months by September 21. At a smaller margin, this campaign also encouraged previously non vaccinated individuals 'taking the vaccination plunge,' due to the growing awareness with the faster diffusion of the delta variant, as well as to other reasons related to preferential treatment of vaccinated individuals in public events and international travel. ${ }^{16}$ Be that as it may this opens the

\footnotetext{
${ }^{14}$ In a cross states study within the US Hansen and Mano (2021) find that economic activity rebounded by more in states with higher fractions of vaccinated individuals. Furthermore, vaccines were relatively more effective in urban areas.

${ }^{15}$ The Bennett government was sworn in on June 13, 2021.

${ }^{16}$ Arce et. al. (2021) report that willingness to get vaccinated in 15 low- and middle-income countries is higher than in the US and Russia.
} 
door for the hope that following a sufficiently potent accumulation of vaccinations infections are likely to recede as well.

Solid knowledge about the ability of sufficiently high proportion of inoculated population to moderate the pandemic is essential since large pools of infected individuals raises the appearance of new variants and with it the probability that some of them may reduce the effectiveness of vaccines. This is particularly important in view of the fact that the current tendency is to live with the virus implying that air traffic, although lower than in the pre-pandemic era, is maintained at levels that facilitates the spread of new variants across the world.

Unfortunately, since vaccines have been around for just a bit over a year than and the fraction of inoculated individuals in many countries is relatively low, there is little statistical information about the ability of high levels of vaccines to also reduce infections. ${ }^{17}$ Such knowledge will most likely accumulate as more countries in the world reach sufficiently high levels of vaccinations. This supports the view that, besides equity considerations, there is a positive externality associated with a more equitable distribution of vaccines across countries (Ghosh (2021)).

Down the road, with new data accumulating it may be possible to refine the statistical analysis along two dimensions. The first concerns a potential differential impact of vaccine types on Covid19 outcomes and the second concerns potential differences in the impact of boosters' types versus broadening the share of vaccinated individuals. Precise discrimination between the impacts of different types requires data on immunization for each type of vaccine in each country -- which is currently unavailable. The second question requires data that would classify Covid19 cases into two bins: one for late joiners into the immunization process and the other with earlier joiners with boosters. Such data is likely to roll out in the not-too-distant future in Israel that has recently accumulated both types of populations.

Since the end of 2021 the much less lethal omicron variant and its various strands became dominant. In retrospect, from the vantage point of December 2022, its observed lower mortality was due not only to the virus composition but also to the continuous growth in the fraction of the

\footnotetext{
${ }^{17}$ A recent exception is Milman et. al. (2021). Using vaccination records and test results collected during the rapid vaccine rollout in a large population from 177 geographically defined communities in Israel, they find that the rates of vaccination in each community are associated with a substantial later decline in infections among unvaccinated individuals.
} 
population that has been inoculated. It is likely that the reduction in new infections during 2022 was also helped by this as well as by the onset of herd immunity due to the growing numbers of individuals that contracted the virus and recovered from it. 


\section{Appendix}

\section{Data description, sources and summary statistics}

$M L I_{t}$ is the ratio between new deaths $\left(N D_{t}\right)$ in week $t$ and a two-week lag on bi-weekly new infections $\left(N I_{t-2}\right)$.

$V_{t}$ is the total number of vaccines per one hundred individuals up to period $t$.

$S_{t}$ is an index of stringency of non-pharmaceutical interventions in period t. It is composed of s a composite measure based on nine response indicators including school closures, workplace closures, and travel bans, rescaled to a value from 0 to 100 (100 = strictest).

$R_{t}$ is the total stock of recovered individuals per million individuals in period $t$. It is calculated as the difference between total infections per million individuals in period $t\left(T I_{t}\right)$ and total deaths per million individuals in period $\mathrm{t}\left(T D_{t}\right)$.

$Y_{t}$ is GDP per capita in period $t$.

$O L D_{i}$ is the fraction of individuals above 65 years old.

All the data is drawn from the site of "Our World in Data". The datasets generated and computing codes implemented in this study are available at the following Dropbox Repository:

https://www.dropbox.com/sh/utcog2eygr09j89/AADscZEdCd8J7Rl2_ 


\begin{tabular}{|c|c|c|c|}
\hline $\begin{array}{l}\text { Summary } \\
\text { statistics }\end{array}$ & $\begin{array}{c}\text { Total Vaccinated } \\
\text { V } \\
\text { Per hundred } \\
\text { individuals }\end{array}$ & & \\
\hline vaxGrp & Mean & Std. Dev. & Obs \\
\hline$[0,40)$ & 11.1 & 11.4 & 1,836 \\
\hline$[40,60)$ & 49.9 & 5.9 & 324 \\
\hline$[60,80)$ & 69.6 & 6.1 & 255 \\
\hline$[80,)$. & 119.9 & 26.1 & 811 \\
\hline Total & 46.9 & 48.6 & 3,226 \\
\hline
\end{tabular}

Vaccinated-
Adj. V
VAdj

Per hundred individuals

\begin{tabular}{|l|r|r|r|}
\hline vaxGrp & \multicolumn{1}{|l|}{ Mean } & \multicolumn{1}{l|}{$\begin{array}{l}\text { Std. } \\
\text { Dev. }\end{array}$} & \multicolumn{1}{l|}{ Obs. } \\
\hline & & & \\
\hline$[0,40)$ & 10.8 & 11.1 & 1,836 \\
\hline$[40,60)$ & 46.4 & 6.4 & 324 \\
\hline$[60,80)$ & 63.7 & 8.2 & 255 \\
\hline$[80,)$. & 98.5 & 18.4 & 811 \\
\hline & & & \\
\hline Total & 40.6 & 39.5 & 3,226 \\
\hline
\end{tabular}

Mean deathsNew ND

Per million people

\begin{tabular}{|l|r|r|r|}
\hline vaxGrp & Mean & \multicolumn{1}{l|}{ Dev. } & \multicolumn{1}{l|}{ Obs. } \\
\hline$[0,40)$ & 3.2 & 4.1 & 1,836 \\
\hline$[40,60)$ & 2.7 & 3.7 & 324 \\
\hline$[60,80)$ & 2.2 & 3.3 & 255 \\
\hline$[80,)$. & 1.4 & 2.2 & 811 \\
\hline & & & \\
\hline Total & 2.6 & 3.7 & 3,226 \\
\hline
\end{tabular}

\author{
Per million people
}

Mean infected New

NI

Mean deaths Tota

TD

Per million people
Per million people

\begin{tabular}{|l|r|r|r|}
\hline vaxGrp & Mean & Std. Dev. & \multicolumn{1}{l|}{ Obs. } \\
\hline & & & \\
\hline$[0,40)$ & 0.0017 & 0.0019 & 1,836 \\
\hline$[40,60)$ & 0.0019 & 0.0048 & 324 \\
\hline$[60,80)$ & 0.001 & 0.0010 & 255 \\
\hline$[80,)$. & 0.0007 & 0.0008 & 811 \\
\hline & & & \\
\hline Total & 0.0014 & 0 & 3,226 \\
\hline
\end{tabular}




\begin{tabular}{|l|r|r|r|}
\hline vaxGrp & Mean & Std. Dev. & \multicolumn{1}{l|}{ Obs. } \\
\hline & & & \\
\hline$[0,40)$ & 708.7 & 807.5 & 1,836 \\
\hline$[40,60)$ & 1127.5 & 967 & 324 \\
\hline$[60,80)$ & 1134.2 & 952.3 & 255 \\
\hline$[80,)$. & 1103.9 & 881.6 & 811 \\
\hline & & & \\
\hline Total & 883.7 & 878.6 & 3,226 \\
\hline
\end{tabular}

\begin{tabular}{|l|r|r|r|}
\hline vaxGrp & \multicolumn{1}{|l|}{ Mean } & $\begin{array}{l}\text { Std. } \\
\text { Dev. }\end{array}$ & \multicolumn{1}{l|}{ Obs. } \\
\hline & & & \\
\hline$[0,40)$ & 150 & 187.1 & 1,836 \\
\hline$[40,60)$ & 149.6 & 163.4 & 324 \\
\hline$[60,80)$ & 124.8 & 169.9 & 255 \\
\hline$[80,)$. & 190.7 & 273.1 & 811 \\
\hline & & & \\
\hline Total & 158.2 & 209.8 & 3,226 \\
\hline
\end{tabular}

Mean infectedTotal

Per million people

\begin{tabular}{|l|r|r|r|}
\hline vaxGrp & Mean & Std. Dev. & \multicolumn{1}{l|}{ Obs. } \\
\hline $\begin{array}{l}\text { Per million } \\
\text { people }\end{array}$ & & & \\
\hline$[0,40)$ & 30982.5 & 28727.4 & 1,836 \\
\hline$[40,60)$ & 52292.6 & 34208.7 & 324 \\
\hline$[60,80)$ & 55766.5 & 35009.1 & 255 \\
\hline$[80,)$. & 73134.1 & 43681.6 & 811 \\
\hline & & & \\
\hline Total & 45678.5 & 38568.1 & 3,226 \\
\hline
\end{tabular}

Total Recovered

$\mathbf{R}$

Per million people

\begin{tabular}{|l|l|l|r|}
\hline vaxGrp & Mean & $\begin{array}{l}\text { Std. } \\
\text { Dev. }\end{array}$ & Obs. \\
\hline $\begin{array}{l}\text { Per million } \\
\text { people }\end{array}$ & & & \\
\hline$[0,40)$ & 30273.8 & 28157.4 & 1,836 \\
\hline$[40,60)$ & 51165.1 & 33628.9 & 324 \\
\hline$[60,80)$ & 54632.3 & 34427.4 & 255 \\
\hline$[80,)$. & 72030.2 & 43190.8 & 811 \\
\hline & & & \\
\hline Total & 44794.7 & 38007.5 & 3,226 \\
\hline
\end{tabular}




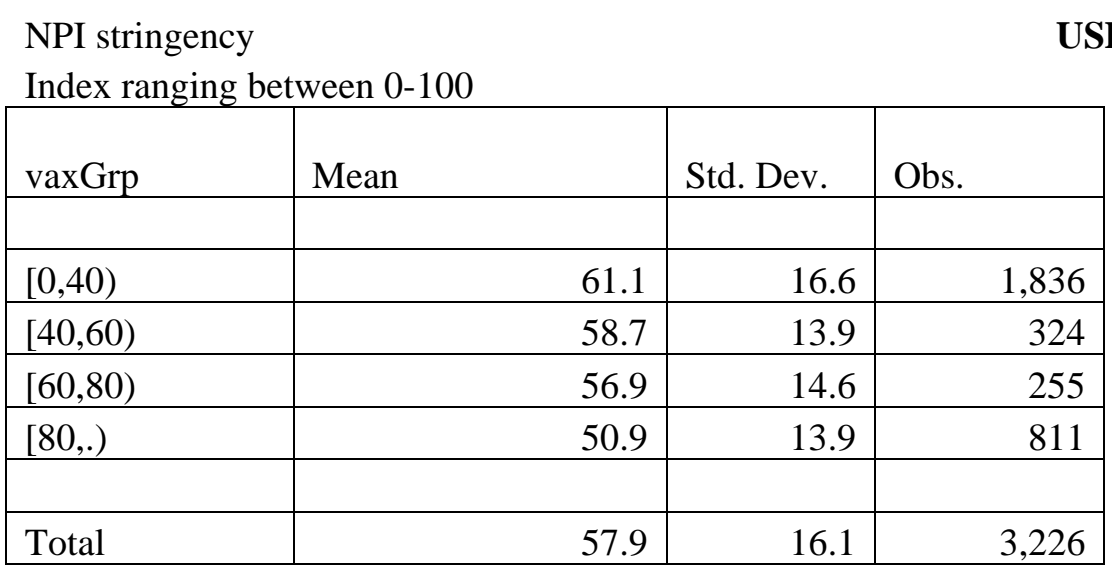

Income
Per capita GDP
\begin{tabular}{|l|r|r|r|}
\hline & Mean & \multicolumn{1}{l}{ Std. } \\
Dev. & \multicolumn{1}{l|}{ Obs. } \\
\hline vaxGrp & & & \\
\hline$[0,40)$ & 22292.1 & 19796.2 & 1,836 \\
\hline$[40,60)$ & 26673.5 & 20130.7 & 324 \\
\hline$[60,80)$ & 29035.6 & 20152 & 255 \\
\hline$[80,)$. & 39467.7 & 22756.1 & 811 \\
\hline & & & \\
\hline Total & 27583.1 & 21847.7 & 3,226 \\
\hline
\end{tabular}

Percent of Population over 65
\begin{tabular}{|l|r|r|r|}
\hline vaxGrp & Mean & Std. Dev. & \multicolumn{1}{l|}{ Obs. } \\
\hline & & & \\
\hline$[0,40)$ & 10.6 & 6.5 & 1,836 \\
\hline$[40,60)$ & 12.2 & 5.9 & 324 \\
\hline$[60,80)$ & 12.6 & 6.1 & 255 \\
\hline$[80,)$. & 13.7 & 6.4 & 811 \\
\hline & & & \\
\hline Total & 11.7 & 6.5 & 3,226 \\
\hline
\end{tabular}




\section{Sample correlations}

\begin{tabular}{|l|l|l|l|l|l|l|l|l|l|l|}
\hline & MLI & ND & NI & V & S & R & TI & TD & Y & OLD \\
\hline MLI & 1.00 & & & & & & & & & \\
\hline ND & 0.07 & 1.00 & & & & & & & & \\
\hline NI & -0.00 & 0.40 & 1.00 & & & & & & & \\
\hline V & -0.06 & -0.18 & 0.08 & 1.00 & & & & & & \\
\hline S & -0.01 & 0.33 & 0.21 & -0.20 & 1.00 & & & & & \\
\hline R & -0.05 & 0.23 & 0.41 & 0.51 & -0.10 & 1.00 & & & & \\
\hline TI & -0.05 & 0.23 & 0.41 & 0.51 & -0.10 & 1.00 & 1.00 & & & \\
\hline TD & 0.04 & 0.62 & 0.20 & 0.22 & 0.01 & 0.65 & 0.66 & 1.00 & & \\
\hline Y & -0.08 & -0.06 & 0.13 & 0.37 & 0.01 & 0.33 & 0.32 & 0.04 & 1.00 & \\
\hline OLD & -0.05 & 0.17 & 0.22 & 0.23 & 0.01 & 0.41 & 0.41 & 0.37 & 0.41 & 1.00 \\
\hline
\end{tabular}


Accounting for depreciation in the effectiveness of vaccines

Table 1a: Impact of depreciation-adjusted vaccines on the mortality to infections ratio

\begin{tabular}{|c|c|c|c|c|}
\hline \multirow[t]{2}{*}{ Regressor } & \multicolumn{3}{|c|}{$\begin{array}{l}\text { Linear Regressions, Dependent variable: } \\
M L I_{i t}\end{array}$} & \multirow{2}{*}{$\begin{array}{l}\text { Logarithmic } \\
\text { Regression, Dependent } \\
\text { variable: } \log \left(M L I_{i t}\right) \\
\underline{\text { Full Sample }}\end{array}$} \\
\hline & $\underline{\text { Full Sample }}$ & $\begin{array}{l}\underline{\text { High }} \\
\underline{\text { Vaccinations }} \\
\end{array}$ & $\begin{array}{l}\underline{\text { Low }} \\
\underline{\text { Vaccinations }}\end{array}$ & \\
\hline$M L I_{i, t-1}$ & $\begin{array}{l}0.71^{* * *} \\
(0.09)\end{array}$ & $\begin{array}{l}0.32 * \\
(0.10)\end{array}$ & $\begin{array}{l}0.83^{* * *} \\
(0.03)\end{array}$ & $\begin{array}{l}0.86 * * * \\
(0.02)\end{array}$ \\
\hline$V_{i, t-2}$ & $\begin{array}{l}-0.02 * \\
(0.01)\end{array}$ & $\begin{array}{l}-0.04^{*} \\
0.02)\end{array}$ & $\begin{array}{l}-0.09 * \\
(0.04)\end{array}$ & $\begin{array}{l}-0.02 * \\
(0.01)\end{array}$ \\
\hline$S_{i, t-1}$ & $\begin{array}{l}-0.03 \\
(0.02)\end{array}$ & $\begin{array}{l}0.00 \\
(0.04)\end{array}$ & $\begin{array}{l}-0.04 \\
(0.03)\end{array}$ & $\begin{array}{l}0.02 \\
(0.03)\end{array}$ \\
\hline$R_{i, t}$ & $\begin{array}{l}-0.07 \\
(0.09)\end{array}$ & $\begin{array}{l}-0.03 \\
(0.06)\end{array}$ & $\begin{array}{l}-0.02 \\
(0.08)\end{array}$ & $\begin{array}{l}0.01 \\
(0.02)\end{array}$ \\
\hline $\mathrm{Y}_{\mathrm{i}}$ & $\begin{array}{l}-0.08 * \\
(0.02)\end{array}$ & $\begin{array}{l}-0.12^{* *} \\
(0.02)\end{array}$ & $\begin{array}{l}-0.06 * \\
(0.02)\end{array}$ & $\begin{array}{l}-0.08 * \\
(0.02)\end{array}$ \\
\hline$O L D_{i}$ & $\begin{array}{l}-0.01 \\
(0.05)\end{array}$ & $\begin{array}{l}-0.09 \\
(0.05)\end{array}$ & $\begin{array}{l}-0.05 \\
(0.03)\end{array}$ & $\begin{array}{l}0.03 * \\
(0.01)\end{array}$ \\
\hline Intercept & $\begin{array}{l}9.39 * * \\
(2.14)\end{array}$ & $\begin{array}{l}14.70^{* * *} \\
(1.85)\end{array}$ & $\begin{array}{l}8.75^{*} \\
(2.85)\end{array}$ & $\begin{array}{l}0.42^{* *} \\
(0.09)\end{array}$ \\
\hline F-stats. & 548.7 & 49.2 & 318.0 & 2197.3 \\
\hline $\begin{array}{l}\text { Adj. R- } \\
\text { squared }\end{array}$ & 0.51 & 0.20 & 0.56 & 0.82 \\
\hline $\begin{array}{l}\text { Number of } \\
\text { observations }\end{array}$ & 3197 & 1163 & 1482 & 2833 \\
\hline
\end{tabular}

Standard errors in parenthesis under the coefficients. $* \mathrm{P}<0.05, * * \mathrm{P}<0.01, * * * \mathrm{P}<0.001$

$M L I_{i t}$ is the ratio between new deaths in week $t$ and a two-week lag on bi-weekly new infections in country $i$. The indices $i$ and $t$ represent respectively the country and week. $V$ is the cumulated number of vaccines per 100 individuals, $S$ is a measure of stringency of containment measures imposed by government, $R$ is a cumulated measure of recovered individuals per million, calculated as the difference between cumulative cases and deaths, $Y$ is 
income per capita in 2019 and $O L D$ is the fraction of individuals above 65 in 2019. Further details and sources appear in the appendix.

Table 2a: Impact of depreciation-adjusted vaccines on new infections

\begin{tabular}{|c|c|c|c|}
\hline \multirow[t]{2}{*}{ Regressor } & \multicolumn{3}{|c|}{ Linear Regressions, Dependent variable: $\Delta I_{i t}$} \\
\hline & Full Sample & $\begin{array}{l}\underline{\text { High }} \\
\text { Vaccinations }\end{array}$ & $\begin{array}{l}\text { Low } \\
\text { Vaccinations }\end{array}$ \\
\hline$\Delta I_{i, t-1}$ & $\begin{array}{l}0.39 * \\
(0.09)\end{array}$ & $\begin{array}{l}0.26 \\
(0.15)\end{array}$ & $\begin{array}{l}0.48 * * * \\
(0.03)\end{array}$ \\
\hline$V_{i, t-2}$ & $\begin{array}{l}0.03 \\
(0.05)\end{array}$ & $\begin{array}{l}-0.11 \\
(0.04)\end{array}$ & $\begin{array}{l}-0.05 \\
(0.15)\end{array}$ \\
\hline$S_{i, t-1}$ & $\begin{array}{l}-0.25 \\
(0.14)\end{array}$ & $\begin{array}{l}-0.43^{*} \\
(0.14)\end{array}$ & $\begin{array}{l}-0.10 \\
(0.11)\end{array}$ \\
\hline$R_{i, t}$ & $\begin{array}{l}-0.88 * * \\
(0.14)\end{array}$ & $\begin{array}{l}-0.51 \\
(0.66)\end{array}$ & $\begin{array}{l}-1.27 \\
(0.67)\end{array}$ \\
\hline$Y_{\mathrm{i}}$ & $\begin{array}{l}-0.06 \\
(0.05)\end{array}$ & $\begin{array}{l}0.02 \\
(0.07)\end{array}$ & $\begin{array}{l}-0.06 \\
(0.05)\end{array}$ \\
\hline$O L D_{i}$ & $\begin{array}{l}0.33 * \\
(0.13)\end{array}$ & $\begin{array}{l}1.11^{*} \\
(0.24)\end{array}$ & $\begin{array}{l}0.21 \\
(0.31)\end{array}$ \\
\hline Intercept & $\begin{array}{l}15.70 \\
(7.98)\end{array}$ & $\begin{array}{l}23.80 * \\
(7.79)\end{array}$ & $\begin{array}{l}9.63 \\
(7.44)\end{array}$ \\
\hline F-stats & 102.1 & 20.7 & 88.6 \\
\hline $\begin{array}{l}\text { Adj. R- } \\
\text { squared }\end{array}$ & 0.16 & 0.09 & 0.26 \\
\hline $\begin{array}{l}\text { Number of } \\
\text { observations }\end{array}$ & 3198 & 1164 & 1482 \\
\hline
\end{tabular}

Standard errors in parenthesis under the coefficients. $* \mathrm{P}<0.05, * * \mathrm{P}<0.01, * * * \mathrm{P}<0.001$

$M L I_{i t}$ is the ratio between new deaths in week $t$ and a two-week lag on bi-weekly new infections in country $i$. The indices $i$ and $t$ represent respectively the country and week. $V$ is the cumulated number of vaccines per 100 individuals, $S$ is a measure of stringency of containment measures imposed by government, $R$ is a cumulated measure of recovered individuals per million, calculated as the difference between cumulative cases and deaths, $Y$ is income per capita in 2019 and $O L D$ is the fraction of individuals above 65 in 2019. Further details and sources appear in the appendix. 
$\underline{\text { Accounting for interactions between dominant variants and vaccines }}$

Table 1b: Impact of depreciation-adjusted vaccines interacted with dominant variants on the mortality to infections ratio

\begin{tabular}{|c|c|c|c|c|}
\hline \multirow[t]{2}{*}{ Regressor } & \multicolumn{3}{|c|}{$\begin{array}{l}\text { Linear Regressions, Dependent variable: } \\
M L I_{i t}\end{array}$} & $\begin{array}{l}\text { Logarithmic } \\
\text { Regression, } \\
\text { Dependent } \\
\text { variable: } \\
\log \left(M L I_{i t}\right)\end{array}$ \\
\hline & $\underline{\text { Full Sample }}$ & $\begin{array}{l}\underline{\text { High }} \\
\underline{\text { Vaccinations }}\end{array}$ & $\begin{array}{l}\underline{\text { Low }} \\
\underline{\text { Vaccinations }}\end{array}$ & $\underline{\text { Full Sample }}$ \\
\hline$M L I_{i, t-1}$ & $\begin{array}{l}0.89 * * * \\
(0.05)\end{array}$ & $\begin{array}{l}0.87 * * * \\
(0.07)\end{array}$ & $\begin{array}{l}0.81 * * * \\
(0.10)\end{array}$ & $\begin{array}{l}0.90 * * * \\
(0.03)\end{array}$ \\
\hline$S_{i, t-1}$ & $\begin{array}{l}-0.02 \\
(0.05)\end{array}$ & $\begin{array}{l}0.02 \\
(0.02)\end{array}$ & $\begin{array}{l}-0.05 \\
(0.04)\end{array}$ & $\begin{array}{l}0.08 \\
(0.09)\end{array}$ \\
\hline$R_{i, t}$ & $\begin{array}{l}-0.01 \\
(0.05)\end{array}$ & $\begin{array}{l}0.12 \\
(0.06)\end{array}$ & $\begin{array}{l}-0.10 \\
(0.10)\end{array}$ & $\begin{array}{l}0.01 \\
(0.01)\end{array}$ \\
\hline$Y_{i}$ & $\begin{array}{l}-0.03 \\
(0.01)\end{array}$ & $\begin{array}{l}-0.02 \\
(0.01)\end{array}$ & $\begin{array}{l}-0.06 \\
(0.03)\end{array}$ & $\begin{array}{l}-0.01 \\
(0.03)\end{array}$ \\
\hline$O L D_{i}$ & $\begin{array}{l}-0.03 \\
(0.04)\end{array}$ & $\begin{array}{l}-0.08 \\
(0.05)\end{array}$ & $\begin{array}{l}-0.02 \\
(0.14)\end{array}$ & $\begin{array}{l}-0.07 * * * \\
(0.01)\end{array}$ \\
\hline$V_{i, t-2} * A l p h a$ & $\begin{array}{l}0.00 \\
(0.01)\end{array}$ & $\begin{array}{l}-0.01 \\
(0.00)\end{array}$ & $\begin{array}{l}0.00 \\
(0.01)\end{array}$ & $\begin{array}{l}-0.01 \\
(0.01)\end{array}$ \\
\hline$V_{i, t-2} *$ Beta & $\begin{array}{l}-0.01 \\
(0.02)\end{array}$ & $\begin{array}{l}-0.33 \\
(0.13)\end{array}$ & $\begin{array}{l}0.03 \\
(0.03)\end{array}$ & $\begin{array}{l}-0.04 * \\
(0.01)\end{array}$ \\
\hline $\begin{array}{l}V_{i, t-2} \\
* \text { Gamma }\end{array}$ & $\begin{array}{l}0.00 \\
(0.00)\end{array}$ & $\begin{array}{l}0.02 * \\
(0.01)\end{array}$ & $\begin{array}{l}-0.02 \\
(0.01)\end{array}$ & $\begin{array}{l}0.01 \\
(0.00)\end{array}$ \\
\hline$V_{i, t-2} *$ Delta & $\begin{array}{l}-0.00 \\
(0.01)\end{array}$ & $\begin{array}{l}-0.01^{* *} \\
(0.00)\end{array}$ & $\begin{array}{l}0.06 \\
(0.05)\end{array}$ & $\begin{array}{l}0.01 \\
(0.01)\end{array}$ \\
\hline$V_{i, t-2} *$ others & 0.01 & 0.00 & 0.03 & 0.02 \\
\hline
\end{tabular}




\begin{tabular}{|l|l|l|l|l|}
\hline & $(0.01)$ & $(0.01)$ & $(0.02)$ & $(0.02)$ \\
\hline Intercept & $\begin{array}{l}3.78 \\
(1.68)\end{array}$ & $\begin{array}{l}2.26 \\
(0.92)\end{array}$ & $\begin{array}{l}7.89 \\
(5.61)\end{array}$ & $\begin{array}{l}0.11 \\
(0.37)\end{array}$ \\
\hline F-stats. & 309.7 & 306.8 & 95.3 & 328.2 \\
\hline Adj. R-squared & 0.84 & 0.90 & 0.84 & 0.86 \\
\hline $\begin{array}{l}\text { Number of } \\
\text { observations }\end{array}$ & 590 & 325 & 181 & 553 \\
\hline
\end{tabular}

Standard errors in parenthesis under the coefficients. $* \mathrm{P}<0.05$, ${ }^{* *} \mathrm{P}<0.01, * * * \mathrm{P}<0.001$

$M L I_{i t}$ is the ratio between new deaths in week $t$ and a two-week lag on bi-weekly new infections in country $i$. The indices $i$ and $t$ represent respectively the country and week. $V$ is the cumulated number of vaccines per 100 individuals, $S$ is a measure of stringency of containment measures imposed by government, $R$ is a cumulated measure of recovered individuals per million, calculated as the difference between cumulative cases and deaths, $Y$ is income per capita in 2019 and $O L D$ is the fraction of individuals above 65 in 2019. Further details and sources appear in the appendix.

Table 2b: Impact of depreciation-adjusted vaccines interacted with dominant variants on new infections

\begin{tabular}{|c|c|c|c|c|}
\hline \multirow[t]{2}{*}{ Regressor } & \multicolumn{3}{|c|}{$\begin{array}{l}\text { Linear Regressions, Dependent variable: } \\
M L I_{i t}\end{array}$} & \multirow{2}{*}{$\begin{array}{l}\text { Logarithmic } \\
\text { Regression, } \\
\text { Dependent } \\
\text { variable: } \\
\log \left(M L I_{i t}\right) \\
\text { Full Sample }\end{array}$} \\
\hline & Full Sample & $\begin{array}{l}\underline{\text { High }} \\
\underline{\text { Vaccinations }}\end{array}$ & $\begin{array}{l}\underline{\text { Low }} \\
\underline{\text { Vaccinations }}\end{array}$ & \\
\hline$M L I_{i, t-1}$ & $\begin{array}{l}0.55^{* * *} \\
(0.03)\end{array}$ & $\begin{array}{l}0.59 * * * \\
(0.05)\end{array}$ & $\begin{array}{l}0.47^{* * *} \\
(0.03)\end{array}$ & $\begin{array}{l}-0.04 \\
(0.11)\end{array}$ \\
\hline$S_{i, t-1}$ & $\begin{array}{l}-0.26 \\
(0.08)\end{array}$ & $\begin{array}{l}-0.40 * * \\
(0.06)\end{array}$ & $\begin{array}{l}0.04 \\
(0.16)\end{array}$ & $\begin{array}{l}-0.36 \\
(0.19)\end{array}$ \\
\hline$R_{i, t}$ & $\begin{array}{l}-0.57 \\
(0.29)\end{array}$ & $\begin{array}{l}-0.22 \\
(0.21)\end{array}$ & $\begin{array}{l}-2.73^{* * *} \\
(0.36)\end{array}$ & $\begin{array}{l}-0.06 \\
(004)\end{array}$ \\
\hline $\mathrm{Y}_{\mathrm{i}}$ & $\begin{array}{l}-0.10^{*} \\
(0.04)\end{array}$ & $\begin{array}{l}0.06 \\
(0.12)\end{array}$ & $\begin{array}{l}-0.37 * \\
(0.11)\end{array}$ & $\begin{array}{l}-0.02 \\
(0.18)\end{array}$ \\
\hline$O L D_{i}$ & $\begin{array}{l}0.35^{* *} \\
(0.07)\end{array}$ & $\begin{array}{l}0.36^{*} \\
(0.13)\end{array}$ & $\begin{array}{l}0.75^{* *} \\
(0.16)\end{array}$ & $\begin{array}{l}-0.05 \\
(0.07)\end{array}$ \\
\hline
\end{tabular}




\begin{tabular}{|c|l|l|l|l|}
\hline$V_{i, t-2} *$ Alpha & $-0.08^{*}$ & 0.02 & 0.10 & 0.10 \\
& $(0.02)$ & $(0.12)$ & $(0.06)$ & $(0.07)$ \\
\hline$V_{i, t-2} *$ Beta & 0.08 & $-0.47^{* *}$ & $0.77^{* *}$ & 0.34 \\
& $(0.08)$ & $(0.09)$ & $(0.19)$ & $(0.15)$ \\
\hline$V_{i, t-2}$ & -0.09 & $-0.04^{*}$ & $-0.15^{* *}$ & 5.93 \\
$*$ Gamma & $(0.06)$ & $(0.01)$ & $(0.04)$ & $(3.82)$ \\
\hline$V_{i, t-2} *$ Delta & -0.08 & $-0.23^{*}$ & 0.51 & 0.04 \\
& $(0.04)$ & $(0.09)$ & $(0.35)$ & $(0.07)$ \\
\hline$V_{i, t-2} *$ others & 0.00 & -0.01 & 0.03 & 0.05 \\
& $(0.04)$ & $(0.06)$ & $(0.06)$ & $(0.06)$ \\
\hline Intercept & $20.01^{* *}$ & $23.20^{* * *}$ & 4.85 & $1.62 *$ \\
& $(3.20)$ & $(3.07)$ & $(9.63)$ & $(0.59)$ \\
\hline F-stats. & 27.4 & 13.6 & 9.6 & 0.6 \\
\hline Adj. R-squared & 0.31 & 0.28 & 0.32 & -0.02 \\
\hline Number of & 590 & 325 & 181 & 553 \\
observations & & & & \\
\hline
\end{tabular}

Standard errors in parenthesis under the coefficients. ${ }^{*} \mathrm{P}<0.05$, ${ }^{* *} \mathrm{P}<0.01,{ }^{* * *} \mathrm{P}<0.001$

$M L I_{i t}$ is the ratio between new deaths in week $t$ and a two-week lag on bi-weekly new infections in country $i$. The indices $i$ and $t$ represent respectively the country and week. $V$ is the cumulated number of vaccines per 100 individuals, $S$ is a measure of stringency of containment measures imposed by government, $R$ is a cumulated measure of recovered individuals per million, calculated as the difference between cumulative cases and deaths, $Y$ is income per capita in 2019 and $O L D$ is the fraction of individuals above 65 in 2019. Further details and sources appear in the appendix.

\section{References}

Arce J.S. et. al. (2021), “Covid19 vaccine acceptance and hesitancy in low- and middle-income countries”, Nature: Medicine, 27,1385-1394, August.

Balázs É., Y, Guillemette, F. Murtin and D. Turner (2021), "Walking the tightrope: Avoiding a lockdown while containing the virus”, Covid Economics, Issue 64, January

CoVariants, Institute of Social and Preventive Medicine, University of Bern, Switzerland \& SIB Swiss Institute of Bioinformatics, Switzerland (brought by Emma Hodcroft). https://github.com/hodcroftlab/covariants/tree/master/web/data

Deb, P., D. Furceri, J. D. Ostry and N. Tawk (2020a), “The Effect of Containment Measures on the Covid-19 Pandemic”, Covid Economics, Issue 19, May. 
Elbe, S., and Buckland-Merrett, G. (2017) Data, disease and diplomacy: GISAID’s innovative contribution to global health. Global Challenges, 1:33-46. DOI: 10.1002/gch2.1018PMCID: 31565258.

Focacci, C.N., Lam, P.H. \& Bai, Y. (2022) Choosing the right COVID-19 indicator: crude mortality, case fatality, and infection fatality rates influence policy preferences, behaviour, and understanding. Nature: Humanities and Social Sciences Communications, 9, 19.

Ghosh J. (2021), “TIF-The political economy of COVID-19 vaccines”. https://www.theindiaforum.in/sites/default/files/pdf/2021/03/05/the-political-economy-of-covid19-vaccines.pdf

Hale Thomas, Sam Webster, Anna Petherick, Toby Phillips, and Beatriz Kira (2020). Oxford COVID-19 Government Response Tracker, Blavatnik School of Government. https://www.bsg.ox.ac.uk/research/research-projects/oxford-covid-19-government-response$\underline{\text { tracker }}$

Hansen N.J. and R. Mano (2021), “The Economic Effects of Vaccines”, Paper presented at the 2021 Jacques Polak Annual Research Conference.

Hodcroft E. B. (2001), “SARS-CoV-2 Mutations and Variants of Interest”, Institute of Social and Preventive Medicine University of Bern, Bern, Switzerland \& SIB Swiss Institute of Bioinformatics, Switzerland. https://github.com/hodcroftlab/covariants

Hubert, O. (2020), "Spacial Distancing: Air Traffic, Covid-19 Propagation and the Cost of Efficiency of Air Travel Restrictions”, Covid Economics, Issue 24, June.

Jinjarak, Y., Ahmed, R., Nair-Desai, S., Xin, W., \& Aizenman, J. (2020). Accounting for global COVID-19 diffusion patterns, January-April 2020. Economics of disasters and climate change, 4(3), 515-559.

Karabulut G., K. F. Zimmermann, M. H. Bilgin and A. C. Doker (2021) “Democracy and COVID-19 Outcomes”, Economic Letters, 203. 109840.

Milman O. et.al. (2021), “Community-level evidence for SARS-CoV-2 vaccine protection of unvaccinated individuals”, Nature: Medicine, 27, 1367-1369, August. 